\title{
Landowners, while pleased with agricultural easements, suggest improvements
}

\author{
Ellen Rilla
}

\section{We extensively interviewed 46 landowners in two northern Bay Area counties and nearby Yolo County to assess their satisfaction with agricultural conservation easements. The landowners in most cases were enthusiastic sellers of the easements; their motivations included cash, keeping land in the family and conservation. They reported generally satisfactory experiences with the easement programs. To a lesser degree they expressed concerns about certain aspects of the easement process, especially negotiations and monitoring, and suggested ways that easement programs can improve their relationships with landowners.}

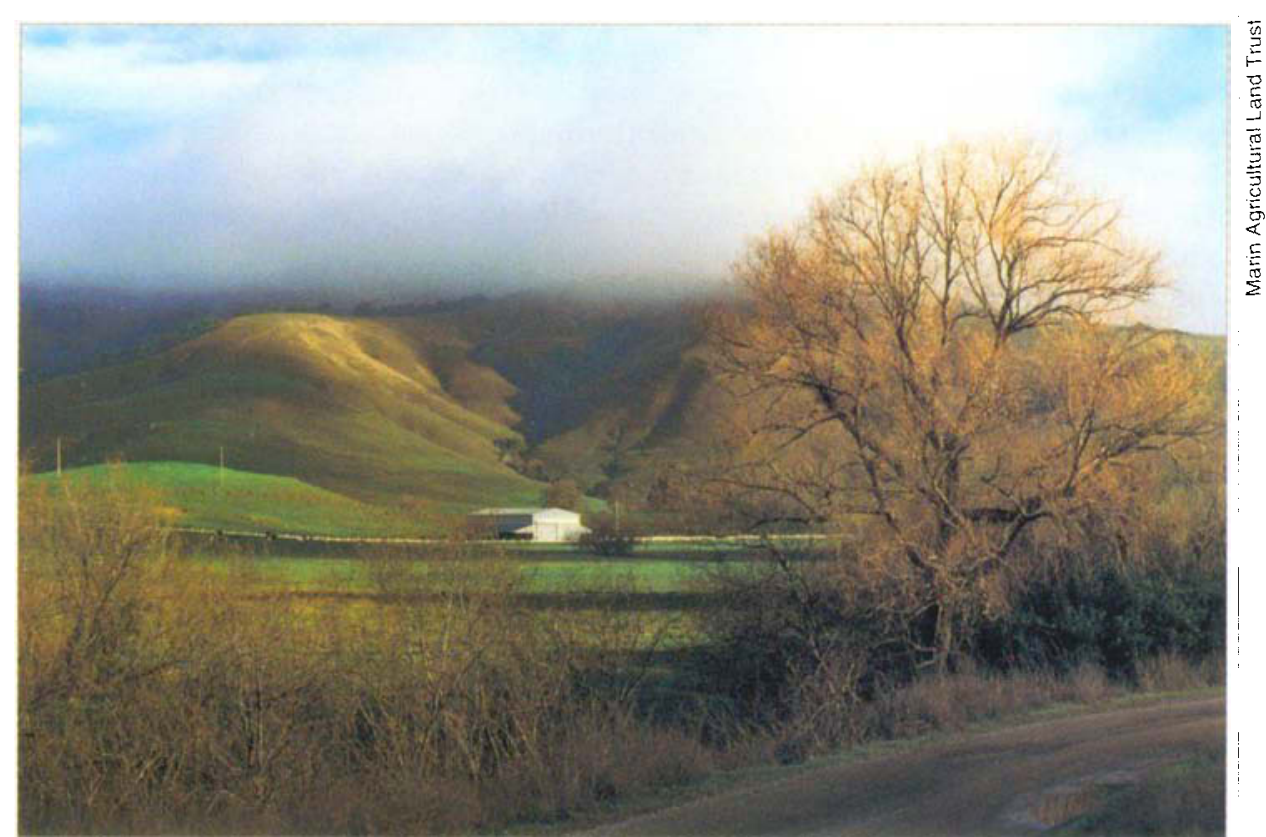

In a survey, the main reasons landowners cited for selling easements were cash, maintaining family ownership and conservation. In Marin County, Marin Agricultural Land Trust's purchase of a 400-acre easement allowed the lelmorini family to buy this dairy, which they had leased for 6 years.

Based on extensive interviews with 46 owners of easement-restricted farms in three counties (Rilla and Sokolow 2000), we have examined landowner motivations for selling easements and their experiences with local programs that acquired the easements (Sherman et al. 1998; Maynard et al. 1998; Elconin and Luzadis 1997). The landowners in most cases were enthusiastic sellers of the easements. Their main motivations were cash, family ownership and conservation, and they reported generally satisfactory experiences with the easement programs. To a lesser degree they expressed concerns about certain aspects of the process, especially negotiations and monitoring, and suggested ways that easement programs can improve their relationships with landowners.

Most of the landowners interviewed are located in two North Bay counties, the region that contains most of California's farmland easement acres and easement programs. Given the unique conservation, landscape and agricultural characteristics of this region, it's not yet clear what the prospects are for easement programs statewide and in the agriculturally rich Central Valley, where they are much less well-established (see p. 22).

\section{Landowners surveyed}

The landowners who participated in this study are involved in three of the most active agricultural easement programs in California. The programs are countywide in scope. The Marin Agricultural Land Trust (formed in 1980) and Yolo Land Trust (formed in 1988) are private, nonprofit organizations, chartered under state law to engage in conservation activities. The Sonoma County Agricultural Preser 